\title{
Web 2.2 Symposium
}

N

$\mathbf{F}$

0

$\mathbf{R}$

$\mathbf{M}$

Á

C

I

ó

S

$\mathrm{T}$

Á

$\mathbf{R}$

S

A

D

Így hivatkozzon erre a cikkre:

Holczer Márton. „Web 2.2 Symposium”.

Információs Társadalom VII, 2. szám (2007): 127-134.

= https://dx.doi.org/10.22503/inftars.VII.2007.2.9

A folyóiratban közölt müvek

a Creative Commons Nevezd meg! - Ne add el! - Így add tovább! 4.0

Nemzetközi Licenc feltételeinek megfelelöen használhatók. 
Holczer Márton

\section{Web 2.2 Symposium*}

2007. február 28-án és március 1-jén a Magyar Telekom Krisztina körúti székházában rendezték meg a második magyarországi Web 2.0 konferenciát. A programot formailag két fő csoportba rendezték: az egyik oldalról a fő szponzorként megjelenó vállalatok mutatták be előadások keretében a web 2.0 jelenségcsokorral kapcsolatos üzletpolitikai lépéseiket, a másik oldalról pedig a többi meghívott pódiumbeszélgetések formájában járt körül egy-egy témát. A szervezók alapvető szándéka a web 2.0 üzleti lehetôségeinek megvitatása és bemutatása volt. Ezt egy technológiai elóadással kívánták megalapozni, miközben maga a web 2.0 fogalma nem került górcső alá.

Az informatikai alapok és trendek bemutatása elốtt Erdélyi Zsolt kapta meg a konferencia nyitóelőadásának lehetôségét. Provokatív bevezetôje jó alapot adhatott volna ahhoz, hogy a web 2.0 fogalmát, az általa leírt jelenségeket megvitathassák a résztvevók. A konferencia szervezói azonban - a program szerkezete szerint - axiómaként értékelték a web 2.0 létjogosultságát, az internet (és az internethasználat) új korszakát, az előadók és a pódiumbeszélgetések résztvevối igazából nem reflektáltak a nyitóelóadásra. Ez azért értékelhetô utólag deficitként, mert sok pódiumbeszélgetés és elhangzott kérdés jelezte, hogy a résztvevók eltérô felfogásban közelítenek a tárgyhoz.

A legfontosabb feszültséget éppen az okozta, hogy a konferencia maga alapvetốen az üzleti lehetőségekre fókuszált. A pódiumbeszélgetések viszont a hallgatóság több tagjából is kicsalták azt a kérdést, hogy a web 2.0 szolgáltatásait miért kellene pusztán az akár a szolgáltatónak, akár a szolgáltató önkéntes tartalomkészítóinek (például a bloggereknek) hozadékként ígért, pénzben kifejezhetô profit nagysága alapján megítélni. Itt úgynevezett long-tail-jelenségról van szó: a web 2.0 eleve nem a „bombaüzlet” terepeként indult, és a jelentôsége a kezdetektól fogva nem (közvetlenül) gazdasági értelemben kiemelkedő. Különösen erôs kontrasztot jelentett, amikor az egyik moderátor a web 2.0-höz tartozónak tekintett, online-formába bújt civil kezdeményezéseken üzleti modelleket és feltétlenül hosszabb távú szándékokat és célokat kért számon.

\section{Létezik-e web 2.0, és ki veszi komolyan?}

Mindenképpen szót kell ejtenünk Erdélyi Zsolt bevezetôjéról. Szerinte még soha nem kapott nevet egy jelenség ennyire gyorsan, mint a web 2.0. Ez már önmagában is felveti azt a gyanút, hogy a téma csupán egy felkapott divatszó köré épül, és valójában

\footnotetext{
* A beszámoló elkészítéséhez az INFINIT-Intelligence Konferencia Tudásbankja nyújtott segítséget. http://www.konferencia-tudasbank.hu
} 
„kamu”. Erdélyi támadta azt a felfogást, miszerint a közösségszervezés új dimenzióba lépett: szerinte például az iwiw csak annyira közösség, mint egy telefonkönyv.

A szakbloggereket a világ nagy része nem is érti az általuk használt szakkifejezések tömege miatt, ezért a leglelkesebb ,propagandisták” tulajdonképpen nagyon szúk körben mozognak, amiból nem tudnak kitörni. Erdélyi a jelek szerint azokat nevezte szakbloggernek, akik a blogokról és a web 2.0 más jelenségeiról múszaki és üzleti szemszögból is írnak, és „központi irányítás nélküli szolgáltatásnak” tekintik azokat. Erdélyi szerint a web 2.0 szolgáltatások igazi üzleti sikerét erôs jogi korlátok határolják be, ugyanis saját tartalomfejlesztés helyett többnyire profi músorkészitóktól, jogi problémákkal terhesen vesznek át tartalmakat.

Egy másik „lelkes csoportra” Erdélyi a „szociológus” címkét adta: ók azok, akik új mozgalmat fedeznek fel a web 2.0-ben, és azt a „bázisdemokrácia” irányába tett üdvös lépésnek tartják. Erdélyi szerint a szabadság persze jó, de „a kontroll nélküli szemét” még nem jelenti a társadalmiság valamiféle új formáját. A web 2.0-hoz sorolt online-tereken nincs különbség vélemény és hiteles információ között. A káosz magasabb szinten való újraszerveződését szerinte utoljára Marx jövendölte meg.

Erdélyi egyedül a web 2.0-alkalmazások által nyújtott új kommunikációs lehetơségeket értékelte nagyra. Rendkívül érdekes kontrasztba került az elmondottakkal a következố elốadó, Németh Norbert, a Sanoma Budapest új médiaosztályának vezetôje, aki közvetlenül nem reagált Erdélyi mondanivalójára, pedig érdemes lett volna, hiszen bizonyos tekintetben inkább alátámasztotta a szkeptikus szavakat. Németh az interaktivitás növelésében látott nagy lehetôséget, sốt az üzleti siker érdekében ezt kötelességnek nevezte. Indoklásával - „a hype az fontos” - azt a meggyốzódését igyekezett propagálni, hogy a marketingszempontok kiemelten fontosak, és az új jelenségvilág felfedezése kimondottan jó hatással van a befektetói aktivitásra. A profi tartalom- és platformszolgáltatók hazai képviselói (legalábbis a saját felfogásuk szerint) mintha mesterséges kis játszóterekkel próbálnák kielégíteni az ügyfelek vagy potenciális fogyasztók igényeit, és az informatikai fejlesztéssel foglalkozó cégek ebben partnereik. Késóbb egy szekcióban Vityi Péter (Microsoft) is csak azt nevezte igazi értéknek a web 2.0-ban, hogy az internet fejlődése segíti a felhasználók tanulását. Amikor a Freemail, az iwiw vagy a Windows Vista bemutatására került sor, hasonló ars poetica volt felfedezhetố a többi nagy cég hozzáállásában is.

Kerese István a Microsoft képviseletében a személyi számítógépek lehetôségeinek és az online-lehetôségeknek a közeledésére mutatott rá: funkcionalitásukban a megjelenítési eszközök (PC, mobiltelefon, beágyazott rendszerek, játékkonzolok, médiacenterek) és a megjelenítési technológiák a böngészố programokon belül és azokon kívül is konvergálnak. Kerese a különbözố gadgetek és widgetek által nyújtott komfortlehetőségek egész sorát mutatta be.

A T-Online vezérigazgatójának, Simó Györgynek az előadása annyiban számított kuriózumnak, hogy ô valóban komolyan próbált helyi értéket találni a web 2.0-ként megjelölt jelenségek számára. A web 2.0-t Simó a web 1.0 „kiigazításának”, az eredeti vízió valóra váltásának, „a genetikusan eredeti potenciál” kiaknázásának tekinti. Szerinte a világhálón akár minden harmadik-negyedik évben elkövetkezhet ilyen „reneszánsz”. Kifejezésre juttatta, hogy akkor tekintheti majd jó befektetésnek az iwiw megvásárlását, ha az valódi „intézménnyé” lesz - minden bizonnyal arra gondolt, 
hogy az iwiw kiemelt szerepet tölthet be a magyar társadalmi életben. A stratégiai irányvonalat a közösségszervezés erósítése (szavazások, kifelé zártabbá tehetố klubok életre hívása), a felhasználó által alkotott tartalom lehetôségeinek megteremtése és a platformközi alkalmazások (iwiw mobil és T-Home TV, valamint gadget és widget típusú alkalmazások) jelzik.

A „Multinacionális nagyvállalatok és az innováció a magyar tartalomiparban” címú beszélgetés során a homályos megfogalmazások ellenére is világosan kitûnt, hogy a multinacionális cégek Magyarországon a tartalomiparban nem törekednek saját fejlesztési programok végrehajtására: számukra kézenfekvóbb megoldás a felvásárlás és az import az anyacégtól. Igaz, a T-birodalom egyes egységei között állítólag nincs intenzív innovációtranszfer. Úgy tûnik, hogy a friss, stratégiai jellegú erôfeszítéseknél azért nem éppen az ilyen elkülönülés a jellemzó: az IPTV esetében páneurópai fejlesztésról beszélhetünk. Az RTL Klub képviselóje, Schönléber Zoltán szerint ezzel együtt is annyi „magyar” van a médiában, amennyit az ország mérete indokol. A beszélgetés vége felé mégis azt hangsúlyozták a résztvevók, hogy a média alapvetốen változik meg napjainkban, de éppenséggel nem a web 2.0 tendenciáira hívták fel a figyelmet, hanem a médiakonvergencia által kiváltott átrendeződésre, melynek következtében a Telekomnak például hamarosan a Yahoo, a Google, netán a Microsoft lehet a vetélytársa.

\section{A technika jelenlegi szintje}

A technikai lehetôségekról és trendekról Neltz Tamás tartott elóadást. A követhetôség szempontjából nagyon jó lett volna, ha nem - saját megfogalmazása szerint is - „old-school” előadást kínál diavetítés nélkül, hanem kihasználja az internetes csatlakozás lehetôségét, amikor sajátosan az internetre szabott alkalmazásokról van szó. Neltz tartalmi szempontból kimerítố elóadása szerint az Internet Explorer 6.0 bevezetése (2001) óta alapvetốen rendelkezésre álltak azok a technikai lehetôségek, amelyekre a web 2.0-nak nevezett alkalmazásvilág támaszkodik. Neltz is megemlítette a tartalmak ,újramixelését” (a teljesen eredeti tartalmak produkálásával szemben - ez a sokat emlegetett mash-up jelenség), valamint a bizalom kérdését, amire a hallgatóság nem kapott kielégítố választ: az internethasználók széles rétege egyelốre bizalommal fordul az új online lehetôségek és tartalmak felé. A felhasználók online azonosíthatóságának megoldására Neltz a személyhez kötődő egyedi azonosítók széles körú alkalmazását elólegezte meg (OpenID). A mobilvilág birtokbavétele esetében a platformok sokféleségét problematikusnak ítélte meg, és a funkcionalitás és a használhatóság szempontjából az Opera Mini böngészốt nevezte meg követendó példaként. A jövoót az OpenID-ben, a világhálón keresztül egyre egyszerúbben megvalósítható közös munkában, a tartalom tekintetében a felhasználókkal való együttmúködésben, valamint az alkalmazásprogramozási interfészek (application programming interface, API) biztosításában látta. Az utóbbiak esetében annak a lehetôségnek a kihasználásáról van szó, hogy a szép karriert befutott programok egyes részeit hozzáférhetôvé és bárki saját céljainak megfelelóen megváltoztathatóvá tehetik, ami lehetővé teszi a tartalmak újrakeverését. 


\section{Vállalati blogok}

A „Nagy cégek, intézmények bloggerei, multis bloggerek: a blog mint vírusmarketing" szekció kényes témát feszegetett: mi a bloggerek és a munkahelyük, illetve a bloggerek és a munkahelyük által nyújtott termékek és szolgáltatások viszonya egymáshoz. Az elóbbi metszetben a felszólalók kevésbé problematikus viszonyról számoltak be, mint amilyen elvileg várható volna: a beszélgetés résztvevối elmondták, hogy egyrészt nem kapnak pénzt a tevékenységükért, a tevékenységük jobbára nincs írásban szabályozva, és leginkább a szakmájukon kívül esô témákról és bizonyos (például politikai) kérdésekról alkotott magánvéleményük közlésétól tartózkodva kerülik el, hogy vállalatuk ügyfeleinek egy részét esetleg elriasszák. Inkább szakmai kérdéseket feszegetnek, és nem igazán voltak feszültségek azzal kapcsolatban, hogy valamilyen üzleti titkot engedély nélkül nyilvánosságra hoztak volna. A felszólalók szerint a blogok vannak annyira személyesek, egyéniek, hogy „vállalati blogként” ne vehessük óket egy kalap alá. Ellentmondtak viszont egymásnak abban a kérdésben, hogy vajon fiktív személyiséggel felruházható-e egy blog abból a célból, hogy azzal egy vállalatot, vállalati egységet, terméket vagy szolgáltatást képviseljenek. Szeszlér Vera (Arcus Interactive Group) szerint ez a megkonstruált szerep múködhet, ha kellően ügyesek az alkotók. Nem zárkózott el ettól a CEU egyetemi tanára, Bögel György, a KFKI-blog szerzóje sem, aki hangsúlyozta, hogy ehhez mindenképpen komolyan kell venni a múfajt, és néhány naponként frissíteni szükséges a blogot. Emellett akkor múködik a dolog, ha a „PR-szag” nem érző́dik az alkotáson - erre a Dell szolgáltat jó példát, ahol a kríziskommunikáció szükségessé válása hívta életre a blogot. Bögel egyetértett abban Máth Andrással (Ringier Kiadó), hogy mivel a munkatársak érvényesülésének a vállalatoknál nem feltétele a jó íráskészség, az ún. „vállalati blogok” száma vélhetốen csak erôsen korlátozott mértékben növekedhet.

\section{Blogszolgáltatók - különbségek az önmeghatározásban}

A blogszolgáltatás üzleti lehetôségeit körüljáró beszélgetés sok szemléleti különbségre vetett fényt. Akadt, aki tartalomszolgáltatóként indult, vagy más okból tartalomszolgáltatóként határozta meg magát, míg mások többnyire valamilyen platformot kínáltak a felhasználóknak. Felmerült az is, hogy esetleg valamiféle evolúciót figyelhetünk meg: a legügyesebb szerzók révén a platformot kínáló szolgáltató elindulhat a tartalomszolgáltatás súlyának növelése felé. A tartalomszolgáltatás viszont óhatatlanul nagy szerkesztối kapacitást igényel. Ennek megfelelóen akadt, aki az önálló blogszolgáltatást nem tartotta hosszú távon életképes megoldásnak, és professzionális tartalomszolgáltatók csatolt szolgáltatásaként jósolt neki felívelő karriert. Egy másik hozzászóló szerint a hírportáloknak nem az egyes blogok, hanem azok gyújteményei lehetnek reális vetélytársai. Volt, aki attól tartott, hogy a legjobb íróit elcsalogatják tóle, míg mások ezt nem tartották veszélynek, a buzz.hu viszont kimondottan és szándékoltan a HSWS előszobájaként múködik. 


\section{A blogkereső és videomegosztó szolgáltatók vitája}

A blogkeresók képviselóinek beszélgetése során ismét hangsúlyt kapott, hogy a bloggerek nem alkotnak jó üzleti célcsoportot: gyakran nem lehet óket elérni, és csoportjuk rendkívül heterogén összetételú. Ennek megfelelően a blogkeresés nem „,biznisz”. Ennél jóval markánsabb véleménykülönbséget tapasztalhattunk a videomegosztó szolgáltatók esetében. Mindössze annyiban mutatkozott egyetértés, hogy a „vicces videók" vonzzák leginkább a felhasználókat.

A pornográf tartalmak külön vitapontot jelentettek. Miskolczy Csaba (videobomb.hu) a határozott elhatárolódás híve (a televízióban használtakhoz hasonló karikákkal jelezné a videofájl megtekintésének „érettségi igényét”), és egy szolgáltatót azzal vádolt, hogy forgalmának jelentôs részét „felnốtt” videók révén éri el. Más felszólalók szerint ezeknek a tartalmaknak az elkülönítése ugyan szerkesztési feladatokat hoz magával, de a számúzésüket nem kell eróltetni, egyébként pedig nem olyan nagy arányban képviselteti magát ez a tartalomtípus, mint sokan sejtetik.

Hazai András (videoplayer.hu) a megosztott videók alábbi három típusát különböztette meg:

- e-mailben vagy más úton másoktól kapott fájlok;

- teljesen amatốr színvonalú, mások számára érdektelen házi videók;

- valóban a közzététel szándékával készült, vágott és szerkesztett felvételek.

Jelentôs nézetkülönbséget tapasztalhatott a hallgatóság, mikor ennek a szolgáltatásnak a jövốbeni kilátásaira terelôdött a szó. Miskolczy Csaba civil médiát tartott kívánatosnak, és a videomegosztókat a professzionális músorkészítés valódi vetélytársainak látta. Szerinte a felvevóeszközök terjedése miatt előfordulhat, hogy az ad hoc közvetítések megelőzik a professzionális músorközlést: a Fidesz parlamenti képviselói által a Kossuth téren végrehajtott kordonbontásról egy videofelvételre alkalmas mobilkészülékkel és egy éppen arra járó újságíró közremúködésével készült az egyik legfrissebb híradás. A videomegosztók esetében vitatott kérdés volt, hogy felléphetünk-e minôségi igényekkel velük kapcsolatban. Többek szerint nem feltétlenül szükséges a músorszórással való versengésre törekedni, de a videomegosztóknak mindenképpen jót tenne, ha növelnék a felhasználóknak a filmkészítéssel (a filmfelvétel technikájával, vizuális és nyelvi kifejezésmódjával) kapcsolatos ismereteiket és készségeiket. Asbóth Attila és munkatársai (freevlog.hu) ehhez készítettek a honlapjukon elérhetô oktatóanyagot.

A véleménykülönbségek a televíziós csatornákkal való versengés tekintetében kevésbé voltak élesek. A médiakonvergencia elkerülhetetlenül bizonyos versenytársi pozícióba hozza az érdekelt feleket. A videomegosztóknak szükségük lenne „profi” tartalomra, és a jelek szerint többnyire Magyarországon is felvették a kapcsolatot a televíziós csatornákkal, hogy szabályozott módon emelhessenek át tólük bizonyos anyagokat. A profi músorszórók számára ez marketinget jelent, és az Egyesült Államokban meglehetôsen nyitottak is erre. Mindenesetre a tévéknek lehetôségük van arra is, hogy a saját honlapjukon tegyék közzé az általuk létrehozott tartalmakat, tehát a további online jelenlétük biztosítására nem éreznek túlságosan erós késztetést. 


\section{Hogyan hirdessünk?}

A „Web 2.0 üzleti modelljei” címú szekció ugyan pusztán a hirdetési lehetôségek megvitatására korlátozódott, mégis a legtartalmasabb szekciók közé sorolhatjuk, mert ezt a leszúkített témát a „mélyfúrás” igényével ragadta meg. Egymás mellett kaptunk pozitív és negatív üzeneteket, „hagyományos” felfogásból fakadó problémafelvetéseket és a web 2.0-vel kapcsolatos szemléletváltás szükségessége mellett szóló érveket. Az egyik alaptétel szerint ez a felület - újdonsága és a fogyasztók nehéz elérhetôsége miatt - nem vonzza a hirdetóket. A kis látogatottság mellett például nem ellenôrizhetó, hogy pontosan milyen tartalom mellé kerül a hirdetés.

Másrészt a beszélgetés számos résztvevôje szerint a pénz oda fog menni, ahova a felhasználó megy. Novák Péter (Kirowski) szerint Magyarországon a web 2.0 esetében ma nincs igazi, múködóképes üzleti modell: a szolgáltatók arra várnak, hogy valamelyik nagy cég felvásárolja óket. A honlapok 99\%-a alkalmatlan a hirdetésre, ráadásul a marketingtechnikák sem elég érettek az új online-terek meghódítására. A hagyományos banner anakronisztikus megoldás.

Berényi Konrád (onlinemarketing.hu) lényegesen optimistább volt: szerinte olyan célcsoportok érhetók el a web 2.0 révén, amelyek máshogyan korábban nem voltak megragadhatók, és ma sem azok. A hatékony hirdetési technikák ki fognak alakulni, ső́t: már akadnak múködő technikák. Novák maga is „,fapados”, de célravezetố megoldást lát az Etarget (http://www.etarget.hu/) és a Google AdSense módszereiben. Kálmán Tamás (etarget.hu) szerint a kisebb kört érintő, de pontosan célzott, költséghatékony eljárások már léteznek, és mindenképpen helyük van a nap alatt. Különösen a véleményvezérek megragadhatóságát hangsúlyozták a vitázók több alkalommal. Kiemelt szempontnak tekintették, hogy a hirdetett termék vagy szolgáltatás összhangban legyen az adott hely tartalmával.

\section{Kik, miről és hogyan írnak?}

Szervetlenül illeszkedett a programba a nói blogokról szóló szekció, hiszen ott az üzleti dimenzió nem jelent meg, holott lehetséges, hogy ennek és a hirdetési szekciónak a kombinálása akár érdekes konkrét példákkal szolgáló, szabályos kis workshop lehetett volna a marketingesek és PR-szakértók számára. A blogírás a chat fórumokon való részvétel, a blogolvasás pedig a könyvolvasás versenytársaként jelent meg a beszélgetésben, és erős hangsúly került a blogírás „terápiás” jellegére, pszichikai jelentôségére.

\section{A "web 2.0 üzleti modellje" nyomában}

A frissen indult (start-up) vállalkozások vitája a következố tanulságokat hozta:

- Nem világos, hogyan is lehet üzletet csinálni egy web 2.0 szolgáltatásból. Ez az állítás még akkor is igaz lehet, ha a szolgáltatás kimondottan felkapottá lett.

- Magyarországon a többség fóként csupán az igen szúkös magyar piacban gondolkodik; ez alól Szántó Gábor egyszemélyes vállalkozása (stubes.net, http://stubes. 
net/) jelentett kivételt, aki angol nyelvú felületet is kínál, és felhasználóinak a fele külföldról veszi igénybe a szolgáltatást.

- A web 2.0 szolgáltatások „szerelemgyerekek”, létrehozóik többnyire szabadidős tevékenységként foglalkoznak velük.

- A marketinget a szolgáltatók lényegében a szóbeszéd erejére bízzák.

Bruckner Zoltán (Primus Capital) megnyugtatta a résztvevóket, hogy az induláskor az angolszász világban sem világos, hogyan is lesz valamiból jövedelmezó tevékenység.

\section{Összefoglalás}

A konferencia sok érdekességet hordozott magában, rengeteg embert mozgatott meg, és korrekt módon zajlott le, de fó célját tekintve deficitesként értékelhetô. Hiányoztak az explicit módon felmutatott üzleti modellek, holott a jelek szerint ez lett volna a kiemelt téma. Utólag érdemes elgondolkodni azon, hogy talán rossz volt a kérdésfeltevés, nem az üzleti lehetôségeket kellett volna szinte kizárólagosan a középpontba emelni.

A konferencia formája a konferenciáról tudósító bloggerek és a videofelvételek ellenére is hagyományosnak volt nevezhetô, és nem tartogatott izgalmakat. Már az is sokat javított volna rajta, ha néhány számítógépen szabadon ki lehetett volna próbálni az említett alkalmazásokat. Érthetetlen, hogy a prezentációk során az internet szinte alig kapott szerepet. A magam részéról azonban azt hiányoltam elsôsorban, hogy a bevezető provokatív gondolatfutam késóbb nem váltott ki tartalmas reflexiókat, pedig erre a lehetőség adott volt.

A web 2.0 körébe sorolt jelenségek a résztvevớk számára kiszámíthatatlan, nehezen befolyásolható és rosszul ellenôrizhetố közegnek tûnhettek. Furcsaságuk abban áll, hogy míg a tömegkommunikáció a 20. században eredményesen orientálta a figyelmet, addig most ennek a peremvidékén hirtelen lehet divatossá vagy megbélyegzetté egy jelenség, termék vagy személy. A web 2.0 vidéke nem hódítható meg a reklámipar bevett eszközeivel. Akadnak új megoldások, lehet bizonyos hullámokat gerjeszteni (hype), de ezek aránytalan és kockázatos befektetésnek túnnek: az eredmény nehezen jósolható meg. Az üzleti szféra azonban még így sem teheti zárójelbe ezt a peremvidéket, ugyanis példának okáért a vállalatok itt gyors reflexiókra lelnek saját termékeikkel és tevékenységükkel kapcsolatban. Másrészt már szinte a semmiból is érkezhet kihívás, amivel a nagy tartalomszolgáltatóknak szembe kell nézniük. A potenciális vetélytársak megjelenése azonban számukra elsôsorban idővel felvásárolható, életképességét már bizonyított üzletágat jelentenek, különösen Magyarországon, ahol a vállalkozó kedvú fiatalok inkább a másutt létrejött „webkettes” innovációk klónjait próbálják megalkotni.

Mindenképpen long-tail jelenségról van szó, Chris Anderson leírása találónak tûnik. A web 2.0-t mozgalomnak nevezni bizonyára túlzás, de e túlzás felbukkanása nem teljesen meglepô. A globális világpiac kiépülésében kulcsfontosságú volt az irányítás forradalma. James Beniger meggyốzốen érvelt amellett, hogy az egyre újabb kommunikációs eszközök használata az üzleti aktorok kontrolljának lehetőségeit a személyes jelenléten, ösztönzésen és büntetésen túl elképesztő mértékben kiterjesztette az alkalmazottak és üzleti partnerek irányába. A tömegkommunikáció és a marketingtechnikák 
a viszonylag jó kiszámíthatóságot hozták magukkal a végfogyasztók igényei terén is. A web 2.0 jelenségcsokorra ezek a módszerek nem húzhatók rá, ez az új világ a kontroll új formáit igényelné - kérdés, hogy a mára hagyományossá lett adminisztratív-bürokratikus kontrollhoz való görcsös ragaszkodás szerencsés befektetés-e. Az üzleti világ ezt a kihívást már jócskán a web 2.0 elôtt észlelte (lásd például outsourcing stratégiai kérdését), így inkább talán más társadalmi szférákra nagyobb nyomás nehezedhet a web „érett korszaka” felól.

Az web2.0-re szabott új hirdetési megoldások kiépülóben vannak (Google AdSense, Etarget), de a jelek szerint nem fenyegetik a fösodort - amennyiben az valamennyire rugalmasan viszonyul hozzá. Az üzleti modellek egy szigorú üzletember szemével nagymértékben ad hoc jellegúek. Sok-sok hirtelen jött siker mögött egyetlen ötlet, egyetlen hobbi, netán egyetlen ember szabadidốs tevékenysége áll. Akiknél már felmerül annak a lehetốsége, hogy újabb szolgáltatásba is fogjanak, ott általában hiányzik ehhez a kapacitás, illetve az üzlet felfuttatására való törekvés. A jelek szerint Magyarországon egyelőre az első felfutás utáni cégeladás marad a jellemző út. Még nem terjedt el a micropayment gyakorlata, és ez sem kedvez a profitszerzố tevékenységeknek, pedig alkalmazása mindenképpen fokozná a hazai „long-tail ” világ jövedelemtermelô képességét.

Konvergenciajelenségek egész sora szabja át a média világában uralkodó viszonyokat, amelyek a reklámiparon és a fogyasztói attitúdök változásán keresztül visszahatnak valamennyi szférára. Ez hosszú folyamatnak tûnik, de az elsố és eredeti válaszreakciók a jelek szerint nem Magyarországon születnek - habár az alacsony tókeigényú web 2.0 esetében a pálya számunkra is nyitottnak látszik. 